\title{
Wrench Tectonism and Intracontinental Basin Sedimentation: A Case Study of the Moku Sub-Basin, Upper Benue Trough, Nigeria
}

\author{
Ifeanyi A. Oha ${ }^{1}$, Ikenna A. Okonkwo ${ }^{1} \&$ Silas S. Dada ${ }^{2}$ \\ ${ }^{1}$ Department of Geology, University of Nigeria, Nsukka, Nigeria \\ ${ }^{2}$ Department of Chemical and Geological Sciences Al-Hikmah University, Ilorin, Nigeria \\ Correspondence: Dr. Ifeanyi A. Oha, Department of Geology, University of Nigeria, Nsukka, Nigeria. E-mail: \\ ifeanyi.oha@unn.edu.ng
}

Received: March 5, 2020

Accepted: March 26, 2020

Online Published: April 30, 2020

doi:10.5539/jgg.v12n1p65

URL: http://dx.doi.org/10.5539/jgg.v12n1p65

\begin{abstract}
The Upper Benue trough of Nigeria consists of basins and horsts characterized by numerous structural features. Detailed study of one of the basins revealed sets of "centimetric", Riedel type "en-echelon" NE-SW trending strike-slip faults contained in a number of brittle and ductile shear zones characterizing the basement/sediment boundary. Structural analysis suggests that the Moku sub-basin has been pulled apart along a releasing bend in between NE - SW strike-slip faults and that three principal axes of stress were acting on the sub-basin during its formation. The maximum stress $\left(\sigma_{1}\right)$ with orientation $34 / 304$ was responsible for the fault overlap (basin length), whereas the minimum stress $\left(\sigma_{3}\right)$ with orientation 18/201 controlled the fault separation (basin width). These suggest a qualitative model showing the Moku sub-basin as a separate basin, which must have coalesced with adjacent sub-basins. Deposition of Bima sediments in the basin was closely controlled by tectonism. The immature $\mathrm{B}_{1}$ sediments are restricted mostly to the faulted margin of the basin. The more matured $\mathrm{B}_{2}$ and $\mathrm{B}_{3}$ sediments are distributed around the less disturbed areas.
\end{abstract}

Keywords: Benue Trough, Riedel faults, paleostress analysis, model, pull-apart basins

\section{Introduction}

Most intracontinental basins are tectonically initiated and bounded by faulted rocks; striations on these rocks reveal different sense of movements that depict various fault types. The geometry and size of a fault-bounded basin depend on the bounding faults, normal faulting on both sides of a basin would result in a graben, while strike-slip faults along releasing or restraining bends could on a regional scale develop into pull-apart basins. Different terms have been adopted roughly synonymous with both structures. Pull-apart basins have been known as tectonic depressions (Clayton, 1966); Wrench grabens (Belt, 1968); Rhomb grabens; rhomb horsts (Aydin and Nur, 1982); and rhombochasms (Gürbüz, 2010). Pull- apart basins are now known to be promising sites of mineral, hydrocarbon and geothermal resources because of typical heat flow, volcanism and intense thickness of clastic reservoir and source rocks (Mann et al., 1983). Classic examples of pull-apart basins include the Mesquite Basin in California (Dooley and McClay, 1997); the sub-basin in the Gulf of Aqaba (Wu et al., 2009) and the Dead Sea basin (ten Brink and Ben-Avraham, 1989).

The Benue Trough is an intracratonic Cretaceous basin about 1,000 kilometres in length and 50 to 100 kilometres wide elongated in the NE-SW direction (Guiraud et al., 1989). It overlies the Precambrian shield of the West African mobile belt and is geographically divided into three regions, from southwest to northeast; the Lower, Middle and Upper Benue Trough which corresponds to different geological features (Allix and Popoff, 1983; Benkhelil, 1989; Maurin et al., 1986). The Upper Benue Trough is Y-shaped, bounded to the west to the northeast by the Pan-African basement and is subdivided into three main domains (Benkhelil, 1989; Guiraud et al., 1989; Abubakar, 2014). To the south, the N150E trending Muri-Lamurde branch. To the east, the E-W trending Yola branch and to the north, the $\mathrm{N} 10^{\circ} \mathrm{E}$ Gongola basin.

The mechanism for the formation of the Benue Trough has been controversial, but most early authors proposed tensional movement resulting in a rift (Cratchley and Jones, 1965; King, 1950). Burke et al. (1971), Grant (1971) and Wright (1968) attributed the origin to the Y-shaped triple junction rift model (RRR) thus defining the Benue basin as an aulacogen seafloor spreading model. More recent work has revealed that wrenching was a dominant 
tectonic process during the Benue Trough evolution (Benkhelil and Robineau, 1983; Benkhelil, 1989, 1986, 1982; Maurin et al., 1986). Field evidence indicates that a set of deep-seated faults is superimposed on the axial high and controlled the tectonic evolution of the Benue Trough (Benkhelil, 1989). The relationship between these faults and the oceanic transform faults has not been satisfactorily explained. However, Benkhelil $(1989,1986,1982)$ and Maurin et al. (1986) proposed that the basins and horsts structure of the Benue Trough were developed along releasing and restraining bends of the faults.

\section{Regional Geology}

In Nigeria the Basement Complex belongs to the West African mobile belt, which has been thoroughly deformed, metamorphosed and granitized during the Pan-African thermotectonic event $600 \mathrm{Ma}$ (Dada et al., 1995, 1993; Rahaman, 1976). The rocks consist mainly of gneisses, migmatites, granitic, monzonitic to charnockitic series, syenites and also relicts of metasedimentary quartzite schists.

In the study area (Figure 2), which lies within the Gongola basin, the Bima Sandstone Formation rests uncomformably on the Precambrian Basement and forms the basal part of the Cretaceous age. A threefold subdivision has been proposed (Guiraud et al., 1989) consisting of a lower shaly unit deposited probably in alluvial fan environments, a middle gravel to coarse-grained sandstone unit probably deposited within large braided stream systems and an upper well-bedded medium to fine-grained texturally homogenous sandstone probably deposited in shallow water lacustrine environment (Suh et al., 1998).

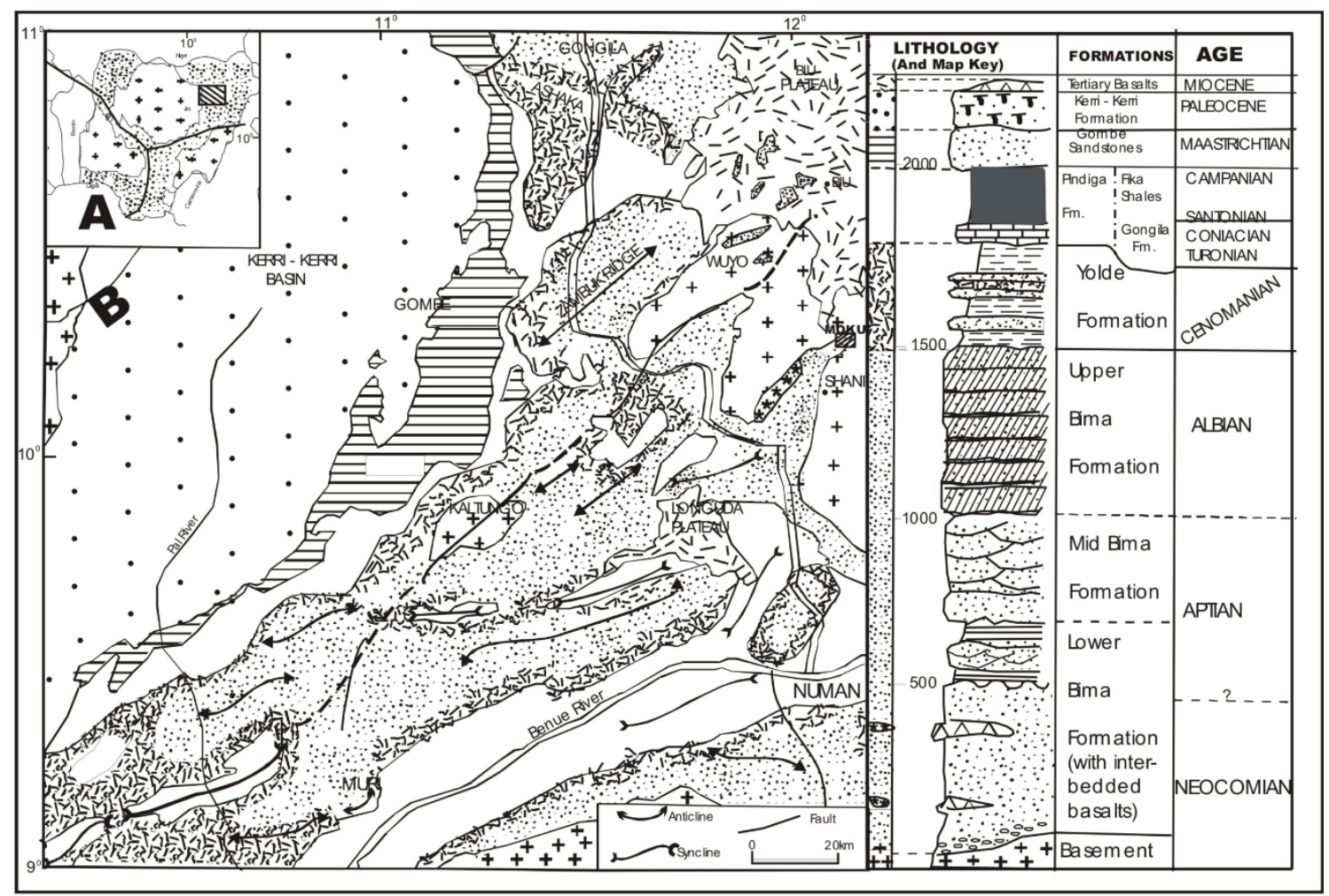

Figure 1. (A) Generalized Geology of Nigeria. (B) Geological map and stratigraphical sequence of the upper Benue Trough (After Rebelle, 1990)

An Aptian to late Albian age has been assigned to the Bima sandstone and is a transitional formation marking the transition from continental to marine sediments. The Pindiga Formation, which is Cenomanian to early Senonian in age, overlies the Yolde Formation and consists of fossiliferrous limestone and shale with interbeds of sandstone, siltstone and shally limestone, the Gombe sandstone Formation is the last member of the Cretaceous Series and includes alternating sandstones, siltstones and ironstone beds, which indicate continental conditions. The flat-lying Keri-Keri Formation is a continental series considered to be Paleocene in age (Adegoke et al., 1978). 


\section{The Moku sub-basin and surrounding rocks}

The study area consists of the NE-SW trending sediment filled Moku sub-basin bounded by deformed and undeformed Precambrian basement rock. Rock relationships both in the sub-basin and its surroundings, present interesting features relating sedimentation to tectonism. The lithologic units of the area can be grouped into three categories, which include crystalline rocks, fault rocks and continental sediments.

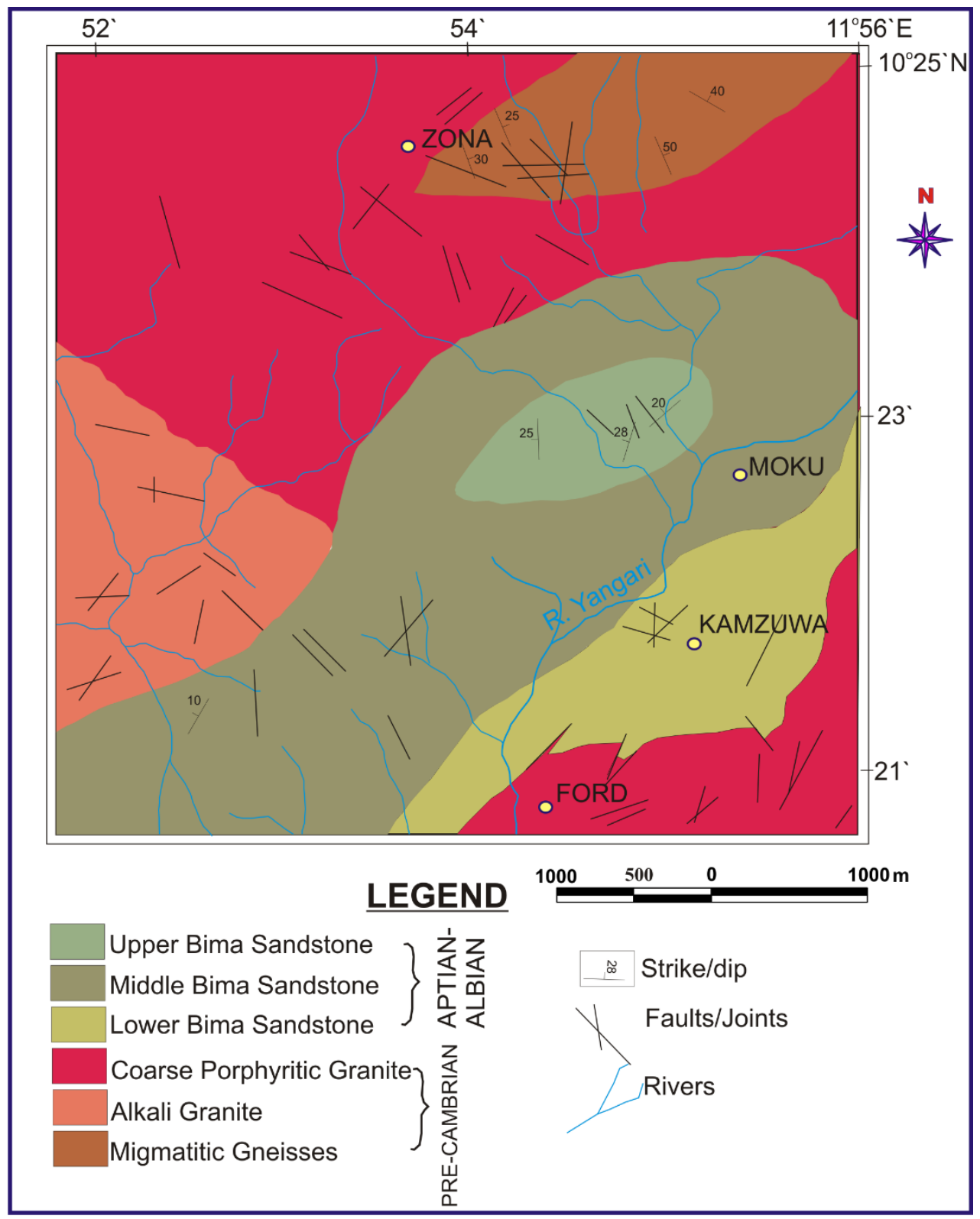

Figure 2. Map Showing the Geology of Part of the Moku Sub-basin and its Surrounding

The crystalline rocks include differentiated granitic rocks and migmatitic gneisses that surround the Moku subbasin. Detailed mapping of the study area has distinguished four rock types. Based on field evidence they are listed in chronology of emplacement; migmatite gneisses, alkali granites, coarse porphyritic granites and microgranitic dykes.

The migmatite gneisses display a hypidiomorpic granular texture. Modal analysis shows an abundance of quartz $30 \%, 30 \%$ microcline, $20 \%$ plagioclase, $8 \%$ biotite, $5 \%$ orthoclase, $2 \%$

Opaques, $2 \%$ hornblende and $2 \%$ accessories. Plagioclase occurs mainly as elongate laths of andesine formed in between the quartz and microcline crystals. The quartz crystals, in this case, are mainly subhedral and exhibits 
undulose extinction. Biotites occur as elongate flaky minerals with a preferred mineral alignment. Under plain light the ferromagnesian minerals mainly biotite forms separate bands of quartz and feldspar. Alteration of biotite to chlorite and iron oxide takes place, especially along cleavages. Accessories include tiny crystals of apatite and zircon.

Alkali granites consist predominantly of microcline $50 \%, 15 \%$ plagioclase, $15 \%$ quartz, $10 \%$ orthoclase, $5 \%$ sericite and muscovite. Numerous pegmatite veins and granitic dykes intrude them. The microcline crystals have started undergoing alterations into thin flakes of sericite and secondary muscovite found in cracks in the fractured crystals. The quartz crystals also have been fractured and are characterized by numerous stacking faults. Plagioclase feldspar, which is mainly oligoclase, has been affected by the microstructures, the twin lamellae are less visible and, in most cases, undergo alteration to reddish trails associated with neo micas. The micas occur mainly as secondary minerals due to alteration of the feldspars, muscovite being the dominant mica.

In hand specimen, the coarse porphyritic granites are pinkish due to predominance of pink $\mathrm{K}$. feldspar. Petrographic studies show $50 \%$ microcline, $25 \%$ quartz, $15 \%$ plagioclase, $10 \%$ biotite and $1 \%$ hornblende. The microcline occurs as large subhedral to euhedral crystals, exhibits distinct crosshatch twin crystals, and in a number of cases found to be perthitic. Blebs of quartz, biotites and muscovites are also found in the large microcline crystals exhibiting poiklitic texture. The quartz grains occasionally occur as phenocrysts but generally constitute the coarse-grained groundmass. The relationships between different quartz grains with other mineral crystals define the characteristic hypidiomorphic intergrowth observed. Plagioclase occurs mainly as medium grained subhedral to euhedral laths of oligoclase. They exhibit clear and distinct polysynthetic twins, and in cases are found exsolved in the larger microcline crystals. The micas are represented by thin flakes of brown weakly pleochroic biotite grains; part of the biotite haven been altered to muscovite and sericite. Accessories include zircon, sphene and apatite.

Microgranite dykes occur mainly as equigranular fine to medium-grained rocks and show a hypidiomorphic granular texture. They are exposed as narrow, discontinuous dykes in the weathered alkali granites.

\subsection{Fault rocks}

These rocks are restricted to brittle-ductile shear zones that define the basement/sediment contact. These shear zones are restricted only to the margins of the basin, and we believe they are responsible for the formation and development of the Moku sub-basin. The rocks include granite breccias, cataclasites, mylonites and brecciated pegmatites.

Granite breccias found in the shear zones are medium to coarse-grained with quartz and microcline porphyroclasts. They are restricted to areas close to the faults bounding the Moku sub-basin, they show evidence of extensive brecciation and fracture, which is as a result of the faulting process. In hand specimen they are reddish-brown in colour, this could be due to the presence of iron oxide, which is an alteration product of brecciation. The breccias are rarely foliated though some of the gray quartz clasts show weak minerals lineation. The quartz grains are mostly fractured grains with angular or irregular boundaries. Most of the quartz grains have been drawn into ribbons during plastic deformation. This is marked by a weak mineral alignment of the quartz grains. Associated with this plastic deformation is a more intense brittle deformation, which involves fracturing of quartz grains, these fractures have been filled by ferromagnesian minerals, which also form pressure shadows around the more resistant quartz grains. Alteration of the feldspar into reddish-brown trails associated with neomica is common. The micas show evidence of alteration. They occur along the line of fractured feldspar or close to the brecciated quartz crystals. Microcline generally shows evidence of alteration to muscovite and sericite, while in plagioclase the deformation has affected the twin lamella enhancing the formation of ghost feldspar.

Cataclasites occur as pockets within the granite breccia; they show evidence of more intense brecciation and are also highly weathered. In the field they show signs of weak foliation defining an alignment of quartz and feldspar clasts accompanied with compositional layering. The quartz and feldspar porphyroclasts are mantled by rims of reddish-brown iron oxide and micas. Mylonites are restricted to the shear zone at the northern part of the basement/sediment boundary; they occur as enclaves among the fault breccias and cataclasites and show evidence of intense deformation.

\subsection{Basin Fill}

The basin is filled with continental sediments of the Bima Formation. The Formation has on a regional scale been well studied and found to be composed of three members namely the Upper Bima member, the Middle Bima member and the Lower Bima member, designated $\mathrm{B}_{3}, \mathrm{~B}_{2}$, and $\mathrm{B}_{1}$ respectively (Carter et al., 1963; Guiraud, 1993; Zaborski et al., 1997) following the description of the various Bima members by Guiraud (1993) and Zarboski et 
al (Zaborski et al., 1997) an attempt is made here to differentiate the Bima sediments contained in the Moku subbasin.

Occurrence of $B_{1}$ sediments is restricted to the faulted margins of the basin (see Figure 2). These sediments consist of coarse-grained poorly sorted highly arkosic sandstone, granule stones and pebbly conglomerates. They occur mainly as massive beds but occasionally occur as poorly defined planner beds. They are devoid of sedimentary structures. The Lower Bima sandstones in the Moku sub-basin could have formed in alluvial fans under a humid climate, probably sourced from uplifted basement rocks surrounding the basin. The effect of tectonism and the high relief of the surrounding basement rocks have caused the sediment to be deposited in a high-energy environment, consequently resulting in poorly sorted coarse-grained sandstone and conglomerates. In hand specimen the $\mathrm{B}_{1}$ sediments are whitish and purplish in colour, quartz makes up greater than $60 \%$ of the rock, feldspar about $30 \%$ and muscovite $5 \%$.

The Middle Bima sandstone is the most abundant sandstones in the Moku sub-basin, and they overlie the $\mathrm{B}_{1}$ sediments. An extensive unconformity between the $\mathrm{B}_{1}$ and $\mathrm{B}_{2}$ has been reported in neighbouring sub-basins (Guiraud, 1993; Zaborski et al., 1997). It consists of medium to very coarse feldspathic sandstones showing both planer and trough cross-bedding. Thick sequences of the Middle Bima are exposed along River Yangari where thick beds (1-3 meters) of $B_{2}$ are seen. Similar sequences in neighbouring basins have been described as proximal braided river systems (Zaborski et al., 1997). Suh et al. (1998) described $B_{2}$ as a high energy braided river deposit. At the Moku hill, thick sequences of $\mathrm{B}_{2}$ sediments were observed to consist of thick intercalations of siltstones and claystones in the sandstone beds. Similar sequences were observed and described as fluviatile episodes with very strong variation of energy levels. Towards the southern part of the basin, $\mathrm{B}_{2}$ consists of medium to coarse-grained feldspathic sandstones, showing both trough and tabular cross-bedding with sets $20 \mathrm{~cm}$ to $100 \mathrm{~cm}$ thick. In other parts of the basin, the medium-grain sequences are laminated and consist of fragmented blocks of ferruginized sandstones. These features are known to occur in upper parts of the fluvial cycles that make up the formation. In hand specimen the $\mathrm{B}_{2}$ shows higher textual and mineralogical maturity than the $\mathrm{B}_{1}$. It is whitish purplish or buff in color and consists of almost $70 \%$ quartz, $20 \%$ feldspar and $10 \%$ mica.

The Upper Bima is restricted only to a small portion of the Moku sub-basin. They form the upper sequence of a NE-SW trending sandstone ridge and were observed as well-bedded medium to fine-grained textually homogenous sandstone characterized by planer cross-bedding and convolute lamination. Contact between the Upper Bima and Middle Bima is not marked by any visible unconformity but in most cases marked by transitional sediments designated $\mathrm{B}_{2} / \mathrm{B}_{3}$. The fine-grained homogenous nature of $\mathrm{B}_{3}$ coupled with its imprinted planer cross lamination and convolute lamination suggest deposition under a shallow water lacustrine environment (Suh et al., 1998).

\section{Paleostress Analysis}

Numerous strike-slip faults, ranging from $5 \mathrm{~cm}$ to approximately $30 \mathrm{~cm}$, were found in the shear zones characterizing the basement/sediment contact. The faults were observed to be generally en-echelon riedel type faults with two major sense of movement (dextral and sinistral). Observations made from slickenside striations show that the more abundant faults are sinistral faults with an average trend of N15E. Dextral faults (less abundant) were observed to have a mean trend of $\mathrm{N} 35 \mathrm{E}$. Wherever they intersect, the N15E sinistral faults were observed to have displaced the $\mathrm{N} 35 \mathrm{E}$ dextral faults. This indicates that the sinistral faults are the younger faults. Zarborski et al, (1997) identified N15E sinistral faults in the sediments along the western boundary of the Gongola arm. Based on these facts, we believe that sinistral faults played a dominant role in the initiation and development of pull-apart basins found in the Upper Benue Trough.

The dynamic significance of brittle fractures and faults has been known to structural geologists for a long time (Anderson, 1951; Pollard and Aydin, 1988). The possibility of statistical analysis of a family of faults found in a particular location can be used to reconstruct the Paleostress field at the time of initiation of faulting. The most common and extensively used method of stress inversion typically involves the use of faults with slickenlines that record the direction of slip relative to the fault plane (Angelier, 1994; Hancock, 1985). Their use is based on the Wallace-Bott hypothesis, which states that the slip on a planar structure is assumed to occur parallel to the greatest resolved shear stress (Bott, 1959). The structures can be used separately or collectively to constrain the stress field that led to their formation. The assumption being that the fractures formed in the same homogenous stress field i.e. related to the same deformational event, that the rocks themselves are fairly homogenous, the fractures do not significantly perturb the stress field in their vicinity and also that the structures have not rotated significantly since their initiation.

The aim of paleostress inversion is to characterize what is known as the reduced stress tensor. The reduced stress tensor has four parameters of the six needed to define the full stress tensor: the principal stress axes $\sigma_{1}$ (maximum), 
$\sigma_{2}$ (intermediate) and $\sigma_{3}$ (minimum) and the ratio of principal stress differences, $R=\left(\sigma_{2}-\sigma_{3}\right) /\left(\sigma_{1}-\sigma_{3}\right)$. The parameter R defines the shape of the stress ellipsoid. Only the directions of the principal stresses (known as Euler angles) can be determined for the stress tensor from inversion. Their relative magnitudes are represented by the fourth parameter R. The two additional parameters of the full stress tensor are the ratio of extreme principal stress magnitudes $\left(\sigma_{1} / \sigma_{3}\right)$ and the isotropic component of the stress tensor (the Mean stress), but these cannot be determined from fault data only.
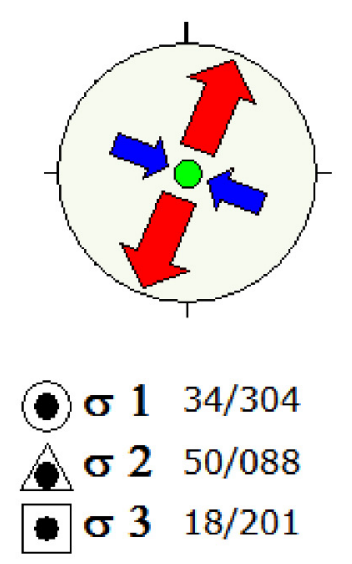

$\mathrm{R}: 0.90$ F5: 128.8 QRw :E QRt :E Function F5
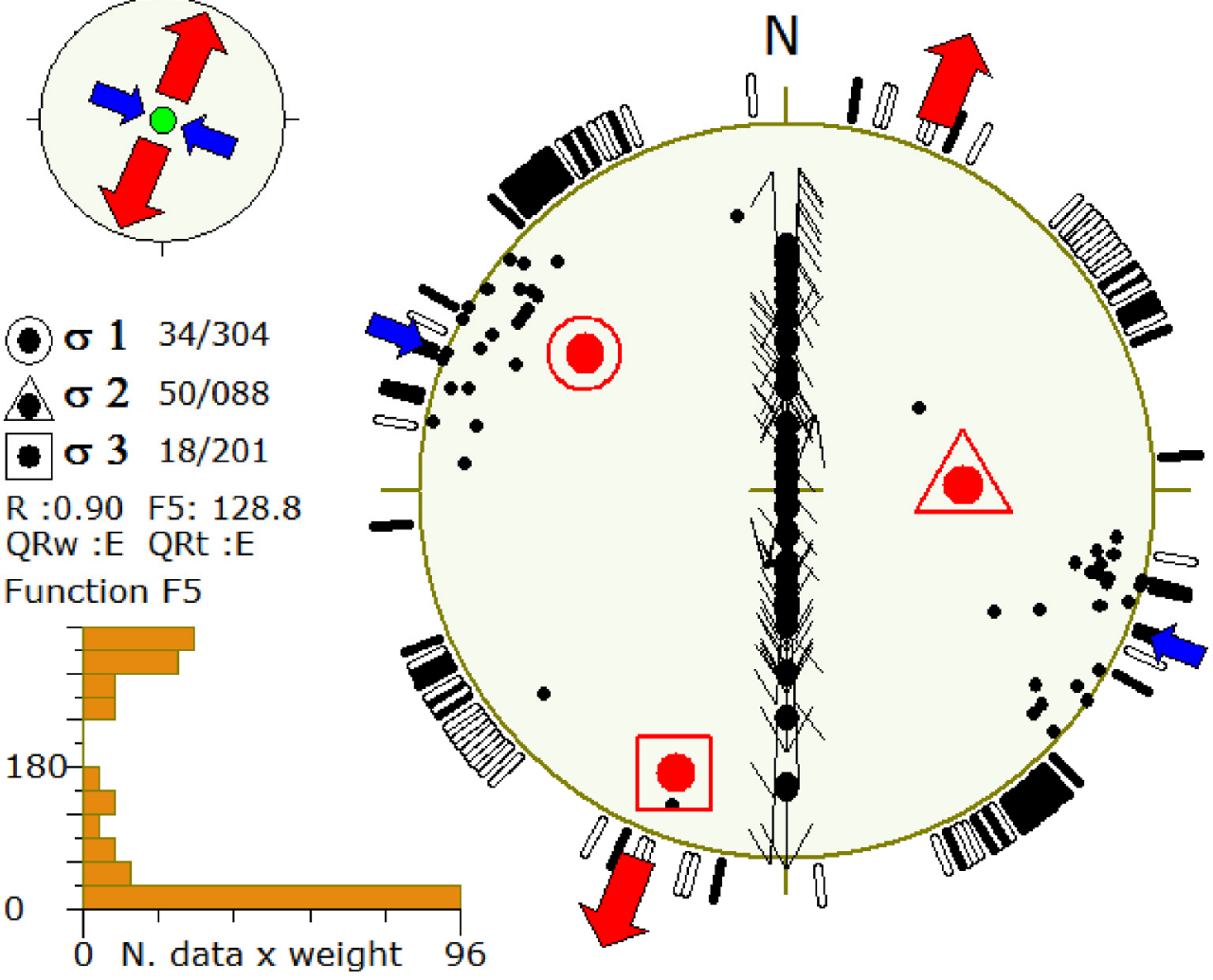

Figure 3. Equal area, stereographic plot of poles of faults with accompanying calculated slips and stress directions

The methods of paleostress inversion are numerical and currently involve the use of computer programmes to statistically analyse fracture data in order to characterize the stress field responsible for them (Angelier, 1994; Célérier et al., 2012; Etchecopar et al., 1981; Hippolyte et al., 2012). This study makes use of TENSOR ${ }^{\text {TM }}$ program (Delvaux and Sperner, 2003; Delvaux, 1993; Delvaux et al., 1997) This program is a tool for controlled interactive separation of fault slip or focal mechanism data and progressive stress tensor optimization using successively the Right Dihedron method and the Rotational Optimization method explained in detail in Delveaux and Sperner (2003). Analysis of tectonic stress from the inversion of fault kinematic and earthquake focal mechanism data is routinely done using a wide variety of direct inversion, iterative and grid search methods. This paper discusses important aspects and new developments of the stress inversion methodology as the critical evaluation and interpretation of the results. The problems of data selection and separation into subsets, choice of optimization function, and the use of non-fault structural elements in stress inversion (tension, shear and compression fractures) are examined. The classical Right Dihedron method is developed in order to estimate the stress ratio R, widen its applicability to compression and tension fractures, and provide a compatibility test for data selection and separation. A new Rotational Optimization procedure for interactive kinematic data separation of fault-slip and focal mechanism data and progressive stress tensor optimization is presented. The quality assessment procedure defined for the World Stress Map project is extended in order to take into account the diversity of orientations of structural data used in the inversion. The range of stress regimes is expressed by a stress regime index R', useful for regional comparisons and mapping. All these aspects have been implemented in a computer program TENSOR. 


\subsection{Results}

Fault orientation and slickenside lineation data from 50 faults determine paleostress directions for the Moku subbasin. From field observations, both the dextral and the sinistral faults were interpreted to have formed at about the same time and were inverted together.

Stress inversion using the Right Dihedron and Rotational Optimization method in TENSOR ${ }^{\mathrm{TM}}$ yielded an extensional strike-slip tensor with parameters $\sigma_{1}=34 / 304 \quad \sigma_{2}=50 / 088$ and $\sigma_{3}=18 / 201$ (see Figure 3 ). The value of $\mathrm{R}=0.9$ and direction of maximum extension being NNE-SSW. The tensor values show an extensional strikeslip or transtensional tectonic regime with extension being in the NNE-SSW direction.

\section{Model}

Some early authors have proposed various models for the development of pull-apart basins (Aydin and Nur, 1982; Burchfiel and Stewart, 1966; Crowell, 1974; Mann et al., 1983). Aydin and Nur (1982) proposed two models for pull-apart development based on worldwide compilation of the dimensions of the 62 active pull-apart basins, which ranged widely in size. These models explained the near-constant length/width ratio established by a relative frequency histogram.

The first model takes into consideration numerous en-echelon fault strands (Figure 4a). Many small grabens appear initially (Figure 4b). As slip increases, the graben begin to coalesce into composite ones (Figure 4c) finally leading to a large basin (Figure 4d).

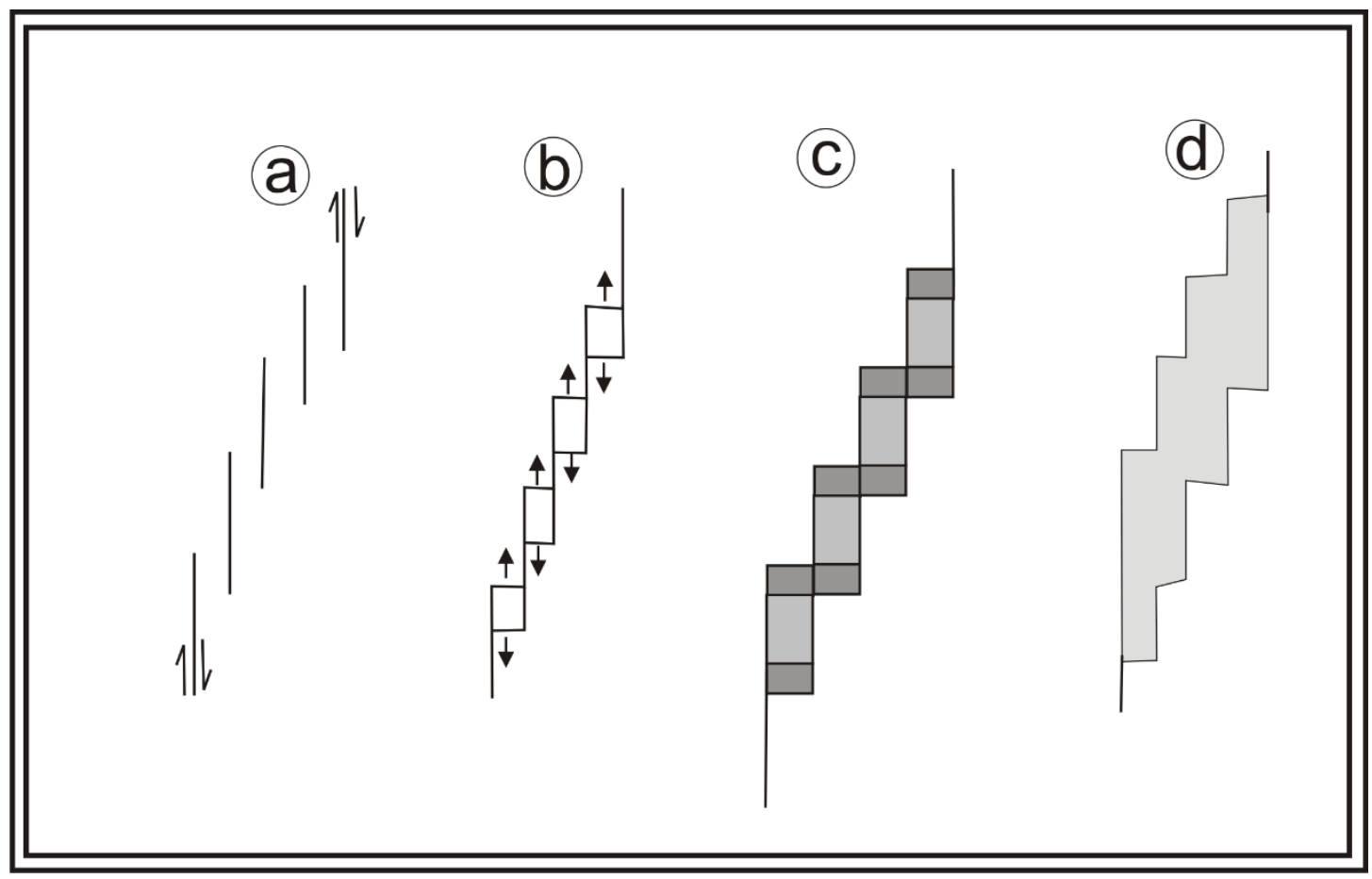

Figure 4. Model 1 (modified from Aydin and Nur, 1982) showing coalescence of rhomb grabens associated with en-echelon strike-slip faults. The end product is a composite pull-apart basin

The second model is based on more random coalescence and interaction processed (Figure 5). Grabens and horsts are produced by interaction among closer and longer fault strands (Figure 5b). New strands form so as to promote further interaction and coalescence, resulting in the formation of longer and wider complex basins and horsts (Figure 5c).

We present a model similar to model 2 (After Aydin and Nur, 1982) proposing that the Moku sub-basin must have been a separate basin but has coalesced into a larger basin as can be seen in Figure 6 . The basins were initiated by the development of large scale en-echelon faults along releasing bends. The faults developed into numerous pullapart basins which with time coalesce into larger basins. This model explains the initiation, development, and evolution of the basins. It is envisaged that this observation would go a long way in solving the long-lasting controversy on the origin and evolution of the entire Benue Trough. 


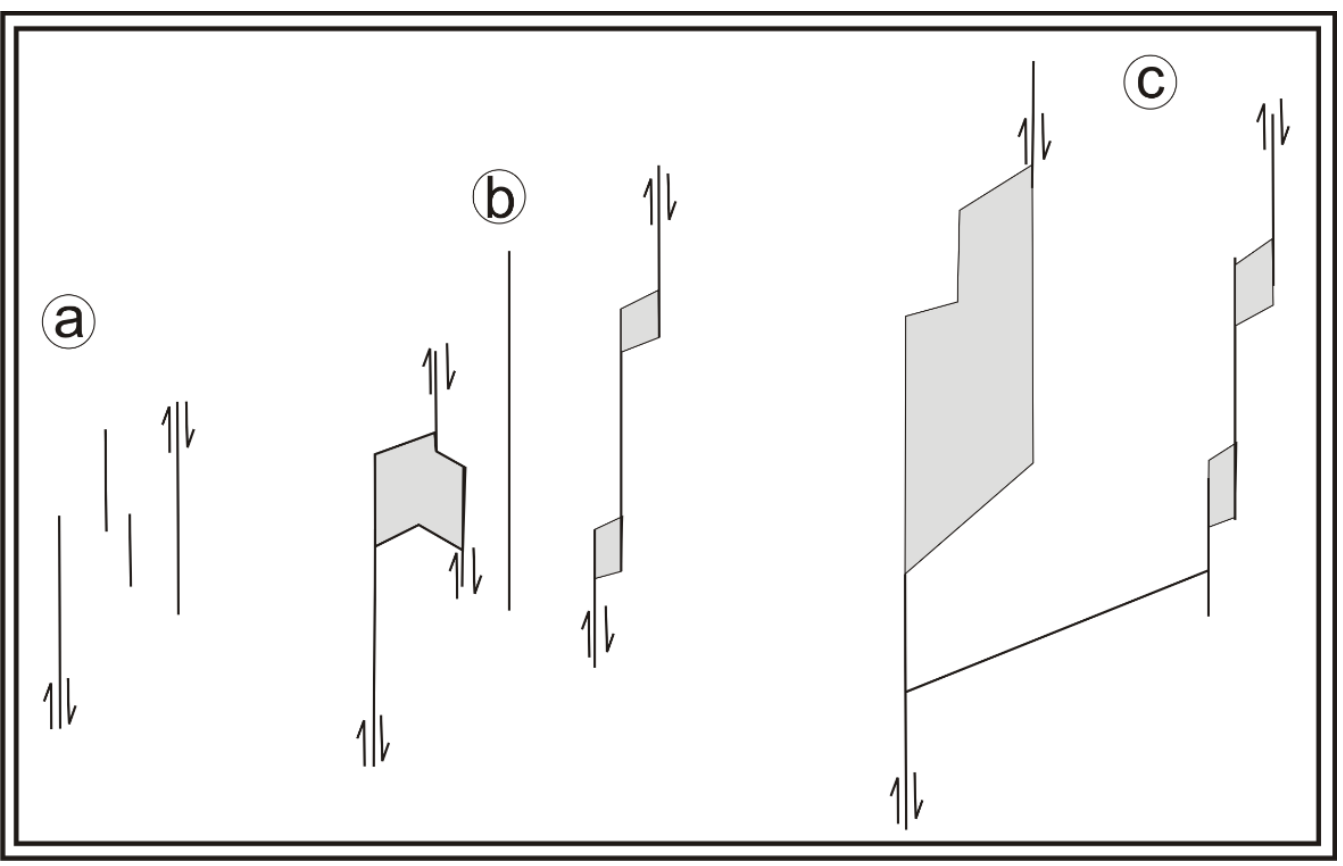

Figure 5. Model 2 (After Aydin and Nur, 1982), illustrates formation of composite pull-apart basin, which includes rhomb grabens and horsts of various size.

(A)

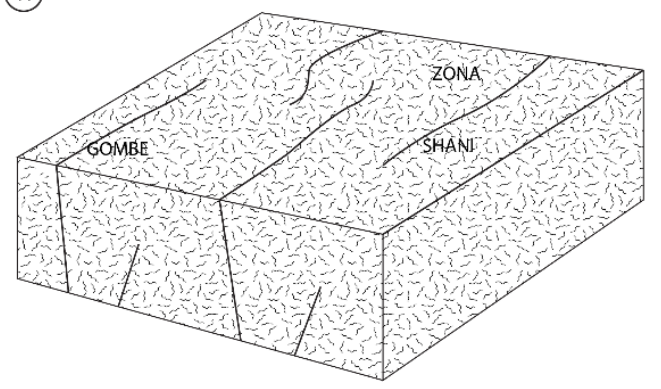

(c)

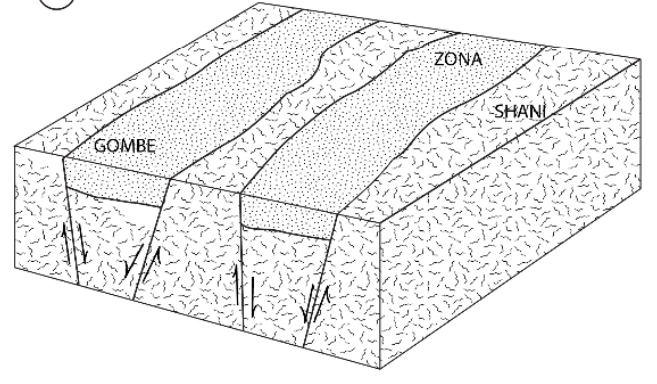

(B)

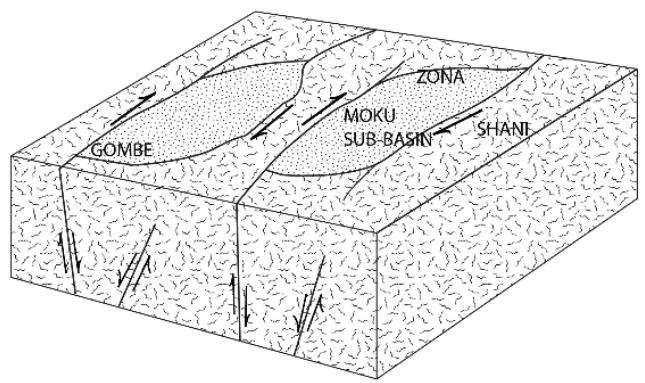

(D)

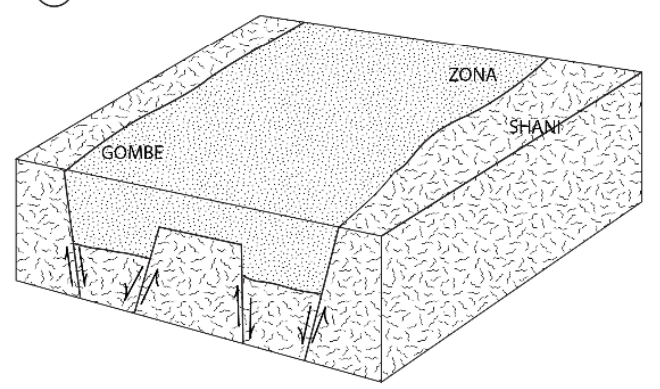

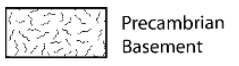
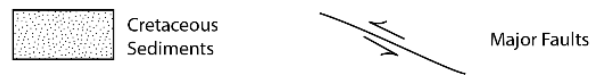

Figure 6. Qualitative model for basins formation in the Upper Benue Trough. (a) Nucleation stage, along releasing and restraining bends of strike slip faults. (b) Individual pull-apart basins are formed, the topmost basin being the Moku sub-basin formed as a separate basin. (c) Pull-apart basins coalesce into larger basins. (d) Larger basins coalesce and develop into a regional rift basin. 


\section{Discussion and Conclusions}

In the real sense, the Moku sub-basin is a part of a larger basin that extends southwards to the Longuda Plateau (Figure 1). Here we propose that the Upper Benue Trough is composed of pull-apart basins, which have evolved through various stages and are now in their extreme stages.

This is for three reasons:

(1) The relative abundance and size of basins with respect to horsts.

(2) General geometry suggests that adjacent basins have coalesced to form larger basins.

(3) Non-preservation in many push-up blocks of record of strike-slip faults, due to continuous tectonism.

Generally, less information can be obtained from the push-up blocks (horsts) bounding the basins where much of the rock record is not preserved. Although the master strike-slip fault could not be traced, an unusual record of enenchelon strike-slip faults were observed around the sub-basin. Fault rocks observed under thin section show predominance of brittle deformation. Sinistral and dextral conjugate faults are contained in the shear zones bounding the basin.

The evolution of the Benue trough has recently been placed in a more regional context, as one of a group of genetically-related basins covering western and central Africa: The West and Central African System (WCARS) (Fairhead et al., 2013). The WCARS model divides the African plate into several segments which moved relative to each other as the entire African plate was separating from the South American. These relative motions were accommodated by strike-slip motions in the Benue trough and tensional motions in some other basins like the Termit basin in Niger. The observations from the Moku basin though on a much more local scale is consistent with the expected tectonic conditions in the Benue trough, especially in the earliest stages of rifting.

Results of this work agree with the proposals made by Benkhelil, (1989, 1986, 1982) and Maurin et al., (1986) that the sub-basins in the Upper Benue Trough were pulled apart between releasing and restraining bends of strikeslip faults resulting to a proliferation of basins and horsts. However, their assertions were based on extrapolations from large scale transform faults. The observations and measurements made around the Moku sub-basin, presents valuable data which put together, throws more light on the origin and evolution of the Benue Trough. Paleostress analysis carried out in this study, suggests the orientation of the Principal Axes of Stress as follows; $\sigma_{1}=34 / 304$ $\sigma_{2}=50 / 088$ and $\sigma_{3}=18 / 201 . \mathrm{R}=0.9$ with the direction of maximum extension being NNE-SSW.

The structural trends and features around the Moku sub-basin have been found to be related to the shape and dimension of the sub-basin. Although evolutional and developmental evidence are yet to be investigated, the following could be concluded from this study.

1) The early Cretaceous event has pulled apart a set of juxtaposed sub-basin, and each sub-basin presents similarities in the features around it (Fairhead et al., 2013; Guiraud and Bosworth, 1997).

2) The Moku sub-basin is formed along a releasing bend in a NE-SW slip direction.

\section{Conflict of interests}

The authors declare that there is no conflict of interests regarding the publication of this paper.

\section{References}

Abubakar, M. B. (2014). Petroleum potentials of the Nigerian Benue Trough and Anambra Basin: A regional synthesis. Natural resources, 5, 25-58. doi: 10.4236/nr.2014.51005

Adegoke, O.S., Jan du Chene, R.E., Agumanu, E.A., \& Ajayi, P.O. (1978). Palynology and age of the Kerri-Kerri Formation, Nigeria. Rev. Espanola Micropal, 10, 267-283.

Allix, P., \& Popoff, M. (1983). Le Crétacé inférieur de la partie nord-orientale du fossé de la Bénoué (Nigeria): un exemple de relation étroite entre tectonique et sédimentation. M Popoff J-J Tiercelin Eds Rifts Fossés Anciens. Bull Centres Rech Explor-Prod Elf Aquitaine, 7, 349-359.

Anderson, E.M. (1951). The Dynamics of Faulting and Dyke Formations. Oliver and Boyd.

Angelier, J. (1994). Fault slip analysis and paleostress reconstruction. Cont. Deform. Pergamon Press Oxf. 53100.

Aydin, A., \& Nur, A. (1982). Evolution of pull-apart basins and their scale independence. Tectonics, 1, 91-105. doi: 10.1029/TC001i001p00091 
Belt, E.S. (1968). Post-Acadian Rifts and Related Facies, Eastern Canada. I n Studies of Appalachian Geology: Northern and Maritime, ed. E-an Zen et al., 95-113. John Wiley \& Sons.

Benkhelil, J. \& Robineau, B. (1983). Le fosse de la Benoue est-il un rift. M Popoff J-J Tiercelin Eds Rifts Fossés Anciens Bull Centres Rech Explor-Prod Elf Aquitaine 7, 315-321. doi: 10.1017/S001675680002584X

Benkhelil, J. (1982). Benue Trough and Benue Chain. Geol. Mag. 119, 155-168.

Benkhelil, J. (1986). Structure and Geodynamic evolution of the Intracontinental Benue trough (Nigeria). Elf Nig Ltd Niger. Bull Centres Rech Explor Prod Elf-Aquitaine, 12, 29-128.

Benkhelil, J. (1989). The origin and evolution of the Cretaceous Benue Trough (Nigeria). Journal of African Earth Science and the Middle East, 8, 251-282. doi: 10.1016/S0899-5362(89)80028-4

Bott, M.H.P. (1959). The mechanics of oblique slip faulting. Geol. Mag, 96, 109-117. doi: $10.1017 / \mathrm{S} 0016756800059987$

Burchfiel, B.C., \& Stewart, J.H. (1966). "Pull-Apart" Origin of the Central Segment of Death Valley, California. Geol. Soc. Am. Bull, 77, 439-442. doi: 10.1130/0016-7606(1966)77[439:POOTCS]2.0.CO;2

Burke, K., Dessauvagie, T.F.J. \& Whiteman, A.J. (1971). Opening of the Gulf of Guinea and Geological History of the Benue Depression and Niger Delta. Nature, 233, 51-55. doi: 10.1038/physci233051a0

Carey, S.W. (1959). The tectonic approach to continental drift. Geology Dept., Univ. of Tasmania.

Carter, J.D., Barber, W., Jones, G.P., \& Tait, E.A. (1963). The Geology of Parts of Adamawa, Bauchi and Bornu Provinces in North-Eastern Nigeria: Explanation of 1: 250,000 Sheets Nos 25, 36 and 47. Federal Government of Nigeria.

Célérier, B., Etchecopar, A., Bergerat, F., Vergely, P., Arthaud, F., \& Laurent, P. (2012). Inferring stress from faulting: From early concepts to inverse methods. Tectonophysics, 581, 206-219. doi: 10.1016/j.tecto.2012.02.009

Clayton, L. (1966). Tectonic depressions along the hope fault, a transcurrent fault in North Canterbury, New Zealand. New Zealand Journal of Geology and Geophysics, 9, 95-104. doi: 10.1080/00288306.1966.10420198

Cratchley, C.R., \& Jones, G.P. (1965). An Interpretation of the geology and gravity anomalies of the Benue Valley, Nigeria. [With maps.].

Crowell, J.C. (1974). Origin of late Cenozoic basins in southern California. Tectonics Sediment. Sepm Spec. Publ. 22, 190-204. doi: 10.2110/pec.74.22.0190

Dada, S.S., Briqueu, L., Harms, U., Lancelot, J.R., \& Matheis, G. (1995). Charnockitic and monzonitic PanAfrican series from north-central Nigeria: Trace-element and $\mathrm{Nd}, \mathrm{Sr}, \mathrm{Pb}$ isotope constraints on their petrogenesis. Chemical Geology, 124, 233-252. doi: 10.1016/0009-2541(95)00010-J

Dada, S.S., Tubosun, I.A., Lancelot, J.R., \& Lar, A.U. (1993). Late Archaean U Pb age for the reactivated basement of Northeastern Nigeria. Journal of African Earth Sciences and the Middle East, 16, 405-412. doi: 10.1016/0899-5362(93)90099-C

Delvaux, D. (1993). The TENSOR program for paleostress reconstruction: examples from the east African and the Baikal rift zones. Terra Nova, 5, 216.

Delvaux, D., \& Sperner, B. (2003). New aspects of tectonic stress inversion with reference to the TENSOR program. Geological Society of London Special Publication, 212, 75-100. doi: 10.1144/GSL.SP.2003.212.01.06

Delvaux, D., Moeys, R., Stapel, G., Petit, C., Levi, K., Miroshnichenko, A., Ruzhich, V., \& San'kov, V. (1997). Paleostress reconstructions and geodynamics of the Baikal region, Central Asia, Part 2. Cenozoic rifting. Tectonophysics, 282, 1-38. doi: 10.1016/S0040-1951(97)00210-2

Dooley, T., \& McClay, K. R. (1997). Analog modeling of pull-apart basins. AAPG Bulletin, 81, 1804-1826.

Etchecopar, A., Vasseur, G., \& Daignieres, M. (1981). An inverse problem in microtectonics for the determination of stress tensors from fault striation analysis. Journal of Structural Geology, 3, 51-65. doi: 10.1016/01918141(81)90056-0 
Fairhead, J.D., Green, C.M., Masterton, S.M., \& Guiraud, R. (2013). The role that plate tectonics, inferred stress changes and stratigraphic unconformities have on the evolution of the West and Central African Rift System and the Atlantic continental margins. Tectonophysics, 594, 118-127. doi: 10.1016/j.tecto.2013.03.021

Grant, N.K. (1971). South Atlantic, Benue Trough, and Gulf of Guinea Cretaceous Triple Junction. Geological Society of America Bulletin, 82, 2295-2298. doi: 10.1130/0016-7606(1971)82[2295:SABTAG]2.0.CO;2

Guiraud, M. (1993). Late Jurassic rifting-early Cretaceous rifting and late Cretaceous transpressional inversion in the upper Benue basin (NE Nigeria). Bull. Centres Rech. Explor.-Prod. Elf Aquitaine, 17, 371-383.

Guiraud, M., Ajakaiye, D.E., \& Ugodulunwa, F.X.O. (1989). Characterisation of late Cretaceous NE-SW sinistral wrench faults in the Upper Benue Trough (Nigeria) using microtectonic and aeromagnetic data. Journal of African Earth Sciences and the Middle East, 9, 9-21. doi: 10.1016/0899-5362(89)90003-1

Guiraud, R., \& Bosworth, W. (1997). Senonian basin inversion and rejuvenation of rifting in Africa and Arabia: synthesis and implications to plate-scale tectonics. Tectonophysics, 282, 39-82. doi: 10.1016/S00401951(97)00212-6

Gürbüz, A. (2010). Geometric characteristics of pull-apart basins. Lithosphere, 2, 199-206. doi: 10.1130/L36.1

Hancock, P.L. (1985). Brittle microtectonics: principles and practice. Journal of Structural Geology, 7, 437-457. doi: 10.1016/0191-8141(85)90048-3

Hippolyte, J.-C., Bergerat, F., Gordon, M.B., Bellier, O., \& Espurt, N. (2012). Keys and pitfalls in mesoscale fault analysis and paleostress reconstructions, the use of Angelier's methods. Tectonophysics, 581, 144-162. doi: 10.1016/j.tecto.2012.01.012

King, L. (1950). Speculations upon the Outline and the Mode of Disruption of Gondwanaland. Geological Magazine, 87, 353-359. doi: 10.1017/S0016756800077311

Mann, P., Hempton, M.R., Bradley, D.C., \& Burke, K. (1983). Development of pull-apart basins. Journal of Geology, 91, 529-554. doi: 10.1086/628803

Maurin, J.C., Benkhelil, J., \& Robineau, B. (1986). Fault rocks of the Kaltungo lineament, NE Nigeria, and their relationship with Benue Trough tectonics. Journal of Geological Society of London. 143, 587-599. doi: 10.1144/gsjgs.143.4.0587

Pollard, D.D., \& Aydin, A. (1988). Progress in understanding jointing over the past century. Geological Society of America Bulletin, 100, 1181-1204. doi: 10.1130/0016-7606(1988)100\%3C1181:PIUJOT\%3E2.3.CO;2

Rahaman, M.A. (1976). Review of the basement geology of southwestern Nigeria. Geology of Nigeria, 41-58.

Rebelle, M. (1990). The Marine transgression in the Benue Trough (N.E. Nigeria) a paleographic interpretation of the Gongila Formation. Journal of African Earth Sciences, 10, 643-656. doi: 10.1016/0899-5362(90)900319

Suh, C.E., Dada, S.S., Ajayi, T.R., \& Matheis, G. (1998). Integrated structural and mineral alteration study of the Zona uranium anomaly, northeast Nigeria. Journal of African Earth Sciences, 27, 129-140. doi: 10.1016/S0899-5362(98)00051-7

Ten-Brink, U.S., \& Ben-Avraham, Z. (1989). The anatomy of a pull-apart basin: Seismic reflection observations of the Dead Sea Basin: Tectonics, 8, 333-350, doi: 10.1029/TC008i002p00333.

Wright, J.B. (1968). South Atlantic continental drift and the Benue Trough. Tectonophysics, 6, 301-310. doi: 10.1016/0040-1951(68)90046-2

Wu, J.E, McClay, K., Whitehouse, P., \& Dooley, T. (2009). 4D analogue modelling of transtensional pull-apart basins. Marine and Petroleum Geology, 26, 1608-1623, doi: 10.1016/j.marpetgeo.2008.06.007

Zaborski, P., Ugodulunwa, F., Idornigie, A., Nnabo, P., \& Ibe, K. (1997). Stratigraphy and structure of the Cretaceous Gongola Basin, northeast Nigeria. Bull. Centres Rech. Explor.-Prod. Elf Aquitaine, 21, 153-185.

\section{Copyrights}

Copyright for this article is retained by the author(s), with first publication rights granted to the journal.

This is an open-access article distributed under the terms and conditions of the Creative Commons Attribution license (http://creativecommons.org/licenses/by/4.0/). 